\section{Biomedical and Biopharmaceutical Research}

Jornal de Investigação
Biomédica e Biofarmacêutica

Códica e Biofarmacêutica

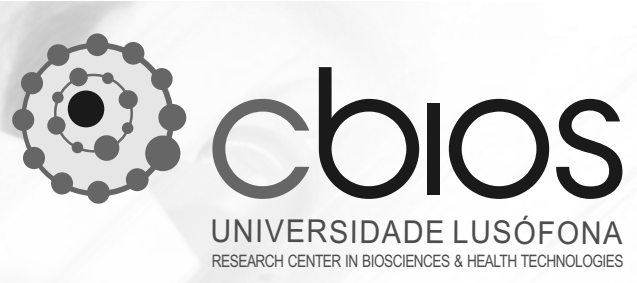

Platform CIÊNCIAVITAE

Plataforma CIENNCIAVITAE

\section{Patrícia Rijo}

CBiOS - Research center for Health Sciences \& Technologies, U. Lusófona, Campo Grande 376, 1749-024 Lisboa, Portuga

\title{
CBiOS Science Sessions - 2018 -
}

\section{Bio-inspired metal-organic frameworks to boost antibiotics activity}

Estruturas orgânicas de metal bio-inspiradas para aumentar a atividade antibiótica

Vânia André

Centro de Química Estrutural Instituto Superior Técnico Universidade de Lisboa, Portugal

\begin{abstract}
O CIÊNCIAVITAE é o sistema nacional de gestão curricular de ciência e é desenvolvido e gerido pela Fundação para a Ciência e Tecnologia (FCT). A plataforma utiliza mecanismos de importação e preenchimento automático dos dados curriculares, assegurando o princípio de reutilização da informação (introduzir uma vez, reutilizar múltiplas), em direta articulação com o Ciência ID. O desenvolvimento da plataforma respeita as melhores práticas e os normativos internacionais, sendo integrável com vários sistemas e identificadores nacionais e internacionais. O CIÊNCIAVITAE agregará num único sítio a informação atualmente dispersa em múltiplas plataformas, de forma simples, harmonizada e estruturada, respeitando as especificidades das áreas científicas e consagrando os princípios da liberdade e da responsabilidade na gestão e na apresentação do currículo.

Venha conhecer a nova plataforma de gestão curricular e faça já o registo CIÊNCIA ID em www.ciencia-id.pt.

Mais informações https://www.cienciavitae.pt/mais-informacao/

\section{Lecturer's resumé}

P. Rijo is a Chemist (1999), MSc in Medicinal Chemistry (2003) and Ph.D. in Pharmacy, specialty in Medicinal Chemistry (2011). From 2002 on, she has published 60 full papers in peer-reviewed international journals indexed to ISI/Scopus/PubMed, 18 papers in other peer-reviewed international journals, 4 book chapters, 35 oral communications, and 2 international patents. She is a member of the editorial board of 3 international journals and Guest editor of two special issues. She received 9 national and 5 international awards. P. Rijo has supervised three Ph.D. theses (completed, one co-supervision) and is currently supervising other seven Ph.D. students (four as co-supervisor). She participated in several national and international Academic Juries (3 Ph.D.). P. Rijo has participated in two funded research projects (1 national and 1 international). P. Rijo is the general secretary of Sociedade Portuguesa de Fitoquímica e Fitoterapia (SPFito) and member of Sociedade Portuguesa de Química, Phytochemical Society of Europe (PSE), and Society for Medicinal Plant and Natural Product Research (GA). P. Rijo is a collaborator of i-MED (Research Institute for Medicines and Pharmaceuticals Sciences) since 2009. P. Rijo is the scientific director for Communication and External Relations of CBiOS and is a member of the scientific council of the degree in Master Integrated in Pharmaceutical Sciences of Universidade Lusófona, ULHT - Lisbon. P. Rijo has integrated the Organizing Committee of several international and national meetings and participates regularly in public outreach activities.
\end{abstract}

\begin{abstract}
Bio-inspired metalorganic frameworks (BioMOFs) are groundbreaking materials that have recently been explored for drug storage, delivery and controlled release, as well as for applications in imaging and sensing for therapeutic and diagnostic. BioMOFs built from nalidixic acid (a quinolone antibiotic) and "safe" metals ( $\mathrm{Zn}, \mathrm{Mn}$ and $\mathrm{Mg}$ ) are going to be discussed. The use of second ligands, such as oxalic and citric acids, has further shown to be successful and it represents a pathway to obtain structures with higher porosity. Mechanochemistry, an environmentally-friendly synthetic technique, has proven to be the most efficient method to synthesize these frameworks. The structure of the new compounds was determined, and their properties assessed, namely the shelf stability, solubility, bioavailability, cytotoxicity and bactericidal activity. The results witness a clear potential of these materials for pharmaceutical application. Importantly, both compounds have proven to increase nalidixic acid antimicrobial activity in the assays using S. aureus, E. faecalis, E. coli, C. albicans, and S. cerevisiae, with the effect against E. coli being most relevant. The emergence of Gram-negative multidrug resistance is of global concern, and BioMOFs may provide a viable alternative to the present antibiotics, due to their increased bactericidal activity.
\end{abstract}

\section{Lecturer's resumé}

Vânia André has a 5-year degree in Chemical Engineering (2004), a pre-Bologna $\mathrm{MsC}$ in Chemical Engineering-Applied Chemistry (2007), and a European PhD in Chemistry (2011), all from Instituto Superior Técnico (IST)/UTL. From 2012 to 2017, she was postdoctoral fellow at Centro de Química Estrutural (CQE) and CICECO, and she is currently a researcher at CQE. Since 2006, she is focused on applying Crystal Engineering and Supramolecular Chemistry towards improving crystal forms of active pharmaceutical ingredients. After extensive studies on polymorphs and multicomponent crystal forms of active pharmaceutical ingredients, she is currently developing bio-inspired metal organic frameworks for enhanced antibiotics activity. Vânia is involved in the design, synthesis and characterization of the novel compounds and always keeps in mind the intended application in the pharmaceutical industry, trying to reach solutions that convene both academia and industry points of view. At the same time, Vânia has a high level of expertise in Crystallography. 